\title{
Religious Education in Sasak Tribe Communities in Disadvantaged Areas
}

\author{
Nunu Ahmad An-Nahidl ${ }^{1}$, Suprapto ${ }^{2}$ \\ \{intersym@gmail.com ${ }^{1}$, supraptolitbang@gmail.com $\left.{ }^{2}\right\}$ \\ Center for Research and Development of Religious and Religious Education, The Ministry of \\ Religious Affairs ${ }^{1,2}$
}

\begin{abstract}
This qualitative research will describe the implementation of religious education in two underdeveloped villages in the Central Lombok Regency, namely Kabul Village and Setiling Village. Identification of religious education services will illustrate equitable access to religious education in disadvantaged areas. Research data collection is done by interview, observation and study documentation. The results of this study explain that religious education institutions in disadvantaged areas have made extraordinary efforts in the process of intellectual intelligence by serving the needs of religious education for school-age residents. The strength is in the high spirit of the community in managing and developing these educational institutions. The government needs to make special efforts and prioritize improving the quality of religious education services in disadvantaged areas so that students can compete with other students in more developed regions.
\end{abstract}

Keywords: Religious Education, Disadvantaged Areas.

\section{Introduction}

Law Number 20 of 2003 concerning the National Education System confirms that national education is rooted in religious values, the national culture of Indonesia and is responsive to the demands of changing times (article 1). The principle of implementing national education is to empower all components of society through their participation in the administration and quality control of education services. Education is carried out in a democratic and fair and non-discriminatory manner by upholding human rights, religious values, cultural values and national diversity (article 4). In this case, every citizen has the same right to obtain a quality education.

The mission of national education is to strive for the expansion and equitable distribution of opportunities to obtain quality education for all Indonesian people. The Government and Local Governments must provide services and facilities and ensure the quality of education for every citizen without discrimination. In this case, citizens who are in remote or backward areas and remote indigenous peoples are entitled to special education services.

Furthermore, Republic of Indonesia Government Regulation number 55 of 2017 on Religious and Religious Education confirms that religious education functions to prepare students to become members of the community who understand and practice the values of their religious teachings and/or become religious scholars (article 1). Religious education aims to form students who understand and practice the values of their religious teachings and/or 
become experts in religious sciences who are broad-minded, critical, creative, innovative, and dynamic in the context of educating the lives of people who believe, have faith, and have good morals.

Referring to the above regulatory basis, the policy direction of the Ministry of Religious Affairs in education matters in 2015-2019 is to improve the quality of religious education services, including a) increasing access to religious education, b) improving the quality of religious education facilities and infrastructure, c) improving the quality of students religious education, d) improving the quality of educators and education personnel of religious education, e) improving the quality assurance of religious education institutions, and f) increasing the quality of moderate religious learning in religious education. Based on the direction of this policy, one of the strategies for implementing Islamic education is to be prioritized through increasing access, quality, relevance and competitiveness of Islamic Religious Education.

Equitable education or equal opportunity to obtain an education is an important issue that was initiated and planned in various countries, especially developing countries. At present, the public is fully aware of the important role of education in the nation's development process, as education democratization develops. Likewise in our country, where the priority for increasing education is evenly distributed, it is directed at the poor people grouping around 38.4 million or 17.6 percent of the total population of Indonesia, based on data from the Central Statistics Agency in 2010.

The problem of poverty is a major obstacle in gaining access to education, especially in poor and remote areas in the underdeveloped category. Such conditions demand the attention of all parties so that social jealousy does not arise in the community. As a country that adheres to the principles of an archipelago, even becoming the largest archipelago in the world, Indonesia has 17,504 large and small islands with a variety of ethnic, cultural and linguistic groups. The distance between one island and another is often separated by a vast ocean. Such a geographical position will impact on the fulfillment of the services of the people's basic needs for education by the government.

The 9-year Basic Education Program initiated by the government through Presidential Instruction Number 1 of 1994 is an effort to serve the basic educational needs of every citizen in all corners of the country. However, the equality of opportunity for education is not simple. Until now, access to education has not been evenly distributed, especially for people living in remote and disadvantaged areas.

By Presidential Decree Number 131 of 2015 concerning Determination of Underdeveloped Regions in 2015-2019, National Development Planning Agency released 122 regencies of cities that are included in the category of disadvantaged areas and become priority priorities in 2015-2019. The area is spread across 34 provinces ranging from Aceh Province to West Papua. Underdeveloped areas are regency areas where the people and their regions are relatively less developed compared to other regions on a national scale (http://kemendesa.go.id/hal/ 300027/183-kab-daerah-tertinggal. Accessed January 25, 2016). Several factors cause it, among others due to geographical reasons, natural resources, human resources, infrastructure and facilities, isolated areas, prone to conflict and prone to disaster.

In this case, Central Lombok Regency in West Nusa Tenggara is one of them. Uniquely, convincing information about the position of disadvantaged areas is not easily obtained. Researchers consulted with Central Lombok Central Statistics Agency and West Nusa Tenggara Province Central Statistics Agency in Mataram to ascertain which sub-districts and villages were included in disadvantaged areas (Central Statistics Agency, interview on February 23, 2016). Likewise, the Ministry of Religious Affairs of Central Lombok Regency 
also seems to lack valid data and information about religious education institutions in disadvantaged areas within their working area.

This condition provides an initial description that religious education policymakers in Central Lombok Regency do not have affirmative action towards the development of education in disadvantaged areas, let alone improve their quality. The indication is obtained from the absence of strong data and information about religious education in disadvantaged areas. Whereas indicators of backwardness are thought to influence education services.

The main focus to be studied in this study is the issue of equal distribution of religious education in disadvantaged areas. This problem is an inseparable part of the issue of equity and broadening access to education in general. The theme of equality and expansion of access to religious education, especially in underdeveloped regions, seems to have not been done an in-depth study. Though religious and religious education is a basic requirement that must be obtained by all muslims.

The aim is to find out how the school-age population in disadvantaged areas have the same opportunity of obtaining religious education at every type and level of education. The existence of religious education in disadvantaged areas is important to identify the distribution of its distribution and examine the extent to which it can serve the needs of religious education in all segments of the surrounding community. Furthermore, people in disadvantaged areas also need to get a quality education. Therefore, the issue of the quality of religious education in disadvantaged areas needs to be positioned as an inseparable part of efforts to improve the quality of national education.

The results of this study are expected to describe the map of the implementation of religious education in two underdeveloped villages in Central Lombok Regency viewed from every aspect of the educational component. Identification of religious education services in the two villages will illustrate a map of equitable access to religious education in disadvantaged areas. The distribution of equity indicates two things; first; how the school-age populations in disadvantaged areas have the same opportunity to obtain religious education at each type and level of education. Second, how religious education can serve the needs of religious education in all segments of society in disadvantaged areas.

\section{Literature review}

Several studies have been conducted on the development of education in disadvantaged areas. Iksan Kahar has researched SDN Inpres Kecil Salena, Buluri Village, Ulujadi District, Palu. The results of his research were published in the IQRA Journal of Educational Sciences and Islamic, Vol. 1, Number 1, July 2018. His findings explain the weaknesses in basic education in disadvantaged areas. For example, the SBC curriculum has not been fully implemented in schools, teachers have not yet succeeded in developing syllabi, so using the syllabus from other schools. Teachers do not base on compiled lesson plans, other than the proposed subjects are not by their expertise [1].

Ariningsih Suciati conducted a study on the Development of the Secondary Education Model in Remote, Disadvantaged and Outermost Regions as an Implementation of citizenship education learning. Discussing in the Social Moral Journal, Vol. 1 Number 1, June 2016, this study explains the potential of regions that are not optimal, increasingly difficult, isolated, and changing. Community education levels are relatively lower, and education services are also lagging. So gathering national insights are needed, as capital of community participation in 
development procurement. Progress in the transition area reflects the Indonesian nation with other countries [2].

This and other studies on promoting formal education in disadvantaged areas. While studies that have studied diniyah and pesantren evaluation have not been conducted. Whereas diniyah and pesantren have an extraordinary role in the process of intelligence of the nation's children. So research that focuses its research on pesantren and diniyah in border areas is very important.

\section{Methodology}

This research uses a qualitative approach. With this approach, it is intended that the data obtained truly illustrates the real reality [3]. The object of research is religious education institutions in disadvantaged areas that were chosen purposively based on the consideration that the religious education institutions concerned have an important role in fulfilling the needs of religious education in disadvantaged areas. The main instrument in this study is the researcher himself [4]. The data collected is qualitative data in the form of words and actions of people observed or interviewed as the main data source [5]. The data sources referred to are the head of the provincial/district/city ministry office, the head of the district/city education and culture office, the village head, the head of the social organization, and the head of the Islamic boarding school or madrasah diniyah.

Data collection techniques used were in-depth interviews, participation observation, documentation studies, and triangulation. The process of analyzing research data is inductive, encompassing data reduction, data categorization, synthesis, and ending with developing a working hypothesis [5].

\section{Results}

\subsection{Overview of Central Lombok Regency}

In Lombok, West Nusa Tenggara, there is a legend about Princess Mandalika who plunged into the high seas at Seger Beach, Kuta, Central Lombok, because it was contested by three princes. The princess then transformed into a sea worm that only comes out once a year based on the calendar calculation of the Sasak Tribe, the original tribe of Lombok. This sacred story encourages Lombok residents to hold the Bau Nyale Festival once a year between February and March. Bau Nyale means "catching worms," in the Lombok language. This research was conducted when Lombok residents rejoiced along the coast of Seger Beach, Kuta Village, Central Lombok Regency to catch Nyale in the February 2016 Bau Nyale Festival.

Bau Nyale and Sasak Tribe are an interesting combination of tourist attractions. The Sasak tribe is a tribe that is still close to the Balinese, but the majority embraces Islam [6]. A small portion of the Sasak tribe practiced a slightly different Islamic teaching, namely Wetu Telu Islam, acculturation between Islamic teachings and local culture that occurred in the past. Wetu Telu's practice is well-known in the Bayan area, North Lombok Regency. While Sasak Boda is a follower of pre-Islamic beliefs, the oldest religion of the Sasak tribe inherited from ancestors. Boda has no connection with Buddhism and Sidharta Gautama. This belief is marked by the worship of the spirits of their ancestors [7] 
The very interesting customs of the Sasak tribe and are still maintained today, among others, are 'merarik' or 'escape.' If women are to be married, then they must be rushed and entrusted to the men's family's family home without the knowledge of their parents, but accompanied by witnesses of their relatives. After a day's stay, the male family sends a messenger to the family of the woman and informs her that her daughter has been stolen and is in an undisclosed location. The group of "survivors" numbered 5 people and were required to dress in custom (Moh. Jalaluddin, the leader of the Nurul Islah foundation, Central Lombok, interview on February 23, 2016).

While the island of Lombok, which is the home of the Sasak tribe, is located on the east side of the island of Bali, separated by the Lombok Strait on the west side of the island, bordering the Upper Strait which separates the island from Sumbawa Island. The area of the island which is included in the province of West Nusa Tenggara is approximately 5435 square kilo meters. Administratively, Lombok Island consists of five districts and cities, namely West Lombok Regency, North Lombok Regency, East Lombok Regency, Central Lombok Regency, and Mataram City. There are around 3 million inhabitants of Lombok Island and $80 \%$ of them are Sasak tribe.

In 2010, Central Lombok Regency experienced a division of 15 villages, so that the number of villages in Central Lombok regency was 139 villages, while the number of subdistricts remained as many as 12, namely; Praya Subdistrict, West Praya Subdistrict, East Praya Subdistrict, Koppang Subdistrict, Jonggat Subdistrict, Pringgarata Subdistrict, Batukliang Subdistrict, Janapria Subdistrict, Pujut Subdistrict, Central Praya Subdistrict, Southwest Praya Subdistrict and North Batukliang [8].

The total area of the Central Lombok Regency is 1.208.39 square kilo meters.. Pujut District is one of the largest subdistricts with an area of 19.33 percent of the total area of the regency, followed by North Batukliang, West Praya and Southwest Southwest Districts with $15.06,12.64$ and 10.34 percent respectively. While other districts have a percentage of the area under seven percent [8].

The northern part is a plateau area and is an area of the foot of Mount Rinjani which includes Batukliang, North Batukliang, Koppang, and Pringgarata Districts. Rainfall in this area is relatively high and can be a support for activities in the agricultural sector, and there are tourism assets, especially mountainous nature tourism. The middle part covers Praya, Central Praya, West Praya, Southwest Praya, East Praya, Janapria and parts of Jonggat District are lowland areas that have the potential of paddy and secondary crops, supported by vast expanses of paddy fields with adequate irrigation facilities. While the southern part is a hilly area and at the same time borders with the Indonesian Ocean, covering the area of Pujut SubDistrict, part of West Praya District, Southwest Praya and East Praya. Because it borders the Indonesian Ocean, this region harbored the potential of beautiful beach tourism with quite fantastic waves [8].

The population of the Central Lombok Regency is 1,040,161 people, consisting of 490,420 men and 549,741 women [9]. The majority of the people of the Central Lombok Regency are believed to embrace Islam. Although there are no recent statistical data found on the number of followers of religion, but referring to the following 2015 data, it seems that the number of followers of religion has not experienced significant changes, namely: Islam $(864,719)$, Protestant (261), Catholic (77), Hindu (3,736), and Buddha (97) (Ministry of National Education Bureau, 2016). Based on these quantity data, Hindus occupy the secondhighest rank after Muslims, followed by Protestants, Buddhists, and Catholics. 


\subsection{Religious Education in Disadvantage Areas}

Central Lombok Statistics Central Board mentions two different sub-district villages that are included in the underdeveloped category, namely Kabul Village in West Praya Sub-district and Setiling Village in North Batukliang District (Central Statistics Agency of Central Lombok, interview on February, 24, 2016). Referring to the statistical data of religious education in Central Lombok Regency in 2015/2016, the development of religious education in the district looks quite evenly distributed in each district. Almost all districts have religious education institutions from various education units, starting from Islamic boarding schools, majelis taklim, diniyah, and especially Qur'anic educational institutions.

This data explains that the total number of religious education units in the Central Lombok Regency was 1843 institutions. This amount can be one indicator that indicates the amount of participation of the people of Central Lombok in the development of education, especially religious education, considering that all religious education institutions were initiated directly and fostered by the community. On the other hand, it also proves the high spirit of the religious diversity of the people and their awareness of the importance of the meaning of religious education.

When compared with formal education both primary and secondary education levels that are spread evenly in each district in Central Lombok Regency, the number of religious education which is non-formal education turns out to be far more.

In total, the number of formal education units in the Central Lombok Regency is 1460 institutions. That is, in quantity this amount is far less than the number of religious education institutions. However, the large quantity of institutional religious education is not directly proportional to the spread of the scope of education services. Because to answer the extent to which school-age students can access religious education institutions at all levels and types, or how religious education can serve the needs of religious education in all segments of society in disadvantaged areas, it can only be known from the number of school-age students registered at each religious education unit. Unfortunately, the author does not obtain detailed data explaining this because the data available at the Ministry of Religion in Central Lombok Regency did not clearly state the number of students in each religious education unit. If the data is obtained, then comparative analysis can be done with the spread of the scope of education services informal educational institutions that have the data.

\subsection{Kabul: Underdeveloped Village on the outskirts of the International Airport}

Anyone who visits Lombok by plane, will land at Lombok International Airport, in Praya, Central Lombok. The 551-hectare airport began operating on November 1, 2011, to replace the Selaparang Airport. About 17 kilo meters east of the airport is a backward village called Kabul Village. This village is included in the area of Southwest Praya District, a sub-district with 11 villages and 121 hamlets which has an area of 124.97 square kilometers, with a population of 67,471 people, consisting of 31,594 men and 35,877 women.

Kabul village with an area of 9.57 square kilometers is one of the villages with an area of less than 10 square kilometers and has a population of 5,386 people, consisting of 2,585 men and 2,801 women. The village, which is a predominantly Sasak tribe, is about 9 kilo meters from Darek, the capital of the West Praya Subdistrict, and 17 kilo meters east of Lombok International Airport and can be reached in 30 minutes by four-wheeled vehicles. 
The access road to Kabul Village is not too wide but is quite good, stretching through the village area with extensive trees and rice fields, starting from Batu Jangkih Village in the north to Plambik Village in the south. In Plambik Village, there is a fairly large dam known as the Pengga Dam. This dam is the source of water that irrigates some villages in West Lombok (Observation, February 25, 2016).

Indicators of Kabul Village lagging in the aspect of transportation facilities seem to have been resolved since the Regional Government built access to hot-mix asphalt roads in early 2015. Now the villagers can easily access the city of Lombok. This development seems to be unknown to Central Statistics Agency of Central Lombok officials who previously said that road access to the village was difficult to pass by car was given the damaged road.

Most Kabul villagers make a living from agriculture. Some of them are farmers who work their land, but unfortunately not much. The size of land ownership is not large. Almost no residents own land on more than 1 hectare. While most of the others are farm laborers. When the corn season arrives, they usually go to Sumbawa to become farm laborers. While some other people went to Malaysia to work in the neighboring country. In general, the people of Kabul Village live a very simple life (TGH Abdullah Lahaji, Head of Ihya Ulumuddin Foundation, interview on February 26, 2016).

Indeed, portraits of Kabul villagers are very commonly found elsewhere, but indications of being left behind due to poor access to road infrastructure seem ironic amid its position which is only a few kilometers from the international airport. This means that there is a social and economic gap that is marked by the emergence of differences in opportunities and the value of benefits that can be felt by the community. Examples of social inequality like this occur a lot between two communities that are actually close together or even side by side. Therefore, serious handling is needed from the authorities, such as the government and community leaders.

On the other hand, Kabul Village has been able to show a pattern of cooperative relations between the government and the community. In the era of the paradigm of good governance, the pattern of relations between the public-private and central-regional sectors has changed to become more equal and democratic. In this pattern, the implementation of certain government services or functions is no longer dominated by just one party, but rather there is a partnership process with various parties.

In the case of Kabul Village, educational institutions have contributed significantly to their role. It does not only provide educational needs services for children of primary and secondary education, even further than that, but educational institutions also become government partners in managing assistance provided by the government. For example, the Ihya Ulumuddin Foundation in Teguh Hamlet, Kabul Village. This educational institution is an extension of the government in channeling routine assistance from the Lombok District Social Service to the elderly who are around Kabul Village. Periodically, the local Social Service provides basic food assistance for 20-80 elderly people. At the lower level, the Ihya Ulumuddin Foundation manages the distribution of aid.

The process shows the political will of local governments to expand internal decentralization and develop cooperation with the public and private sector so that it will have a direct impact on the format of public service institutions. The need to strengthen the collaboration model above can be seen from three aspects; first, political, namely creating democratic governance, and to encourage the realization of good governance and good society. Second, administrative, namely the limitations of government resources, both in terms of budget, human resources, assets, and management capabilities. Third, it is economical, 
namely reducing inequality or inequality, spurring growth and productivity, increasing quality and continuity, and reducing risk [10].

In Kabul Village there are a number of non-formal religious educational institutions managed by the local community, namely three Qur'anic educational institutions (Qur'aniyah, Nurul Hidayah and Hidayatus Shalihin), three Madrasah Diniyah (Ihya Ulumuddin, AzZainiyah NW and Nurul Ijtihad), two boarding schools (Ihya Ulumuddin and Mambaul Ulum), and one majelis taklim, namely Ihya Ulumuddin.

The educational institutions in Kabul Village, it seems that the Ihya Ulumuddin al-Ma'arif Foundation which is located in Teguh Hamlet, Kabul Village, Southwest Praya District is the institution that manages the most education units, starting at diniyah, pesantren, majelis taklim, Ibtidaiyah, Tsanawiyah, to Aliyah.

This foundation initially organized majelis taklim activities. The institute, which is led by Ustadz M. Alimudin, S.Pd.I, was established in 2009. The majelis taklim is the center of religious activities for the surrounding village residents. No less than 100 worshipers attend recitation activities which are held every Saturday night in this majelis taklim. In fact, the place used as extraordinary recitation is simple. A mushalla with a wall without plaster measuring about $10 \times 10$ meters, its position is in the corner of the pesantren complex, among other simple buildings.

In 2011, the foundation opened a diniyah education led by TGH Zainal Abdullah Lahaji, a teacher who has been studying diniyah since childhood. At present, the number of students of Madrasah Diniyah is 65 students and the institution has obtained permission from the Ministry of Religious Affairs. Furthermore, in 2013, the foundation opened a boarding school. The institute, which is led directly by Ustadz Suherman, as the chair of the foundation, organizes teaching activities for male and female students. As with the physical building of the musholla, the hostel for santri is no less simple (Suherman, teacher of Ihya Ulumuddin Foundation, interview on February 26, 2016)

Santri who lives at the Ihya Ulumuddin Foundation as many as 100 people from around 300 students who study in various education units managed by the foundation. They are the people who came from the area around Kabul Village. The furthest distance from the student's house to school is $20 \mathrm{~km}$, which is the residents around Selong Blanak Beach.

The male santri dormitory is made of bamboo booths that are already very fragile and have asbestos roofs which are also starting to decay. The position of the hostel is to the east of the mushalla. As for female students, they occupy the back of TGH Abdullah Lahaji's house. For early childhood, the foundation opens early childhood education programs which is attended by 31 students, as well as the Qur'anic educational institutions which currently has 43 students.

Not only non-formal educational institutions, Ihya Ulumuddin Foundation also manages a number of formal education units, consisting of Madrasah Ibtidaiyah which opened in 2008 and now has 79 students, Madrasah Tsanawiyah which opened in 2011 and currently has 76 students, and Aliyah Madrasah which opened in 2014 with 41 students, which is currently entering its second year, so that there are only classes 1 and class 2 . All educational units managed have obtained establishment permits except Madrasah Aliyah (Suherman, teacher of Ihya Ulumuddin, interview on February 26, 2016).

The development of religious education in Kabul Village is also more complete because there are a number of public education managed by the Ministry of Religious Affairs, such as Ibtidaiyah Ulumuddin, Ibtidaiyah Baitussalam, Ibtidaiyah Sirajul Ulum, and Ibtidaiyah Mambaul Ulum. For the level of Tsanawiyah, namely Tsanawiyah Ihya Ulumuddin and Tsanawiyah Baitussalam. As for the Aliyah level, namely, Aliyah Mambaul Ulum. 


\subsection{Setiling: The Village of the Underdeveloped at the Foot of Mount Rinjani}

Setiling Village is included in the area of North Batukliang District, a sub-district with 8 villages and 90 hamlets which has an area of 181.96 square kilometers, with a population of 57,666 people, consisting of 26,715 men and 30,951 women. Setiling Village with an area of 37.62 square kilometers is one of the four villages in North Batukliang District whose area is more than 35 square kilometers, in addition to Aik Berik Village, Lantan Village, and Karang Sidemen Village. Even though it has a fairly wide area, Setiling Village only has a population of 6,336 people, consisting of 2,891 men and 3,445 women [8].

The position of Setiling Village is in the middle of Lombok Island and is about 8 kilo meters from Teratak, the capital city of North Batukliang district to the south. The village can be reached in about 1.5 hours from Lombok International Airport with a distance of about 35 kilo meters. The access road to the village of Setiling can be traversed from the PrayaMantang highway or Praya-Kopang highway towards the Tourism road, passing through the oldest and historic tourist attractions in the city of Lombok which is crowded during holidays, namely the Aik Bukak baths. The location of the baths that were said to have been built in the Dutch period gives a different feeling because it is surrounded by a large green forest with a fresh tropical atmosphere considering its position around Mount Rinjani. The water that flows into the pool also comes from the spring of Mount Rinjani [8].

As with Kabul Village, the indicator of Setiling Village is in the aspect of transportation facilities because of its position around Mount Rinjani. Since the local government built asphalt road access in early 2015 . Now the village community can reach the city of Lombok easily. The road to the village of Setiling meandered between the thick green trees and the extent of rice fields.

The Setiling villagers depend on agriculture for their livelihood, especially since the village is located in the north bordering the forest area of Mount Rinjani National Park. In the village, there is the Forestry Extension Pilot Unit (FEPU), a community empowerment unit formed by the Central Lombok District Government. The FEPU in Setiling Village is the only forestry extension pilot location in West Nusa Tenggara, and one of the five FEPUs in Indonesia [11].

In the village of Setiling there are a number of non-formal religious education institutions run by the local community, namely the four institutions of the Qur'anic educational institutions (Raudlatul Ijtihad, Sulthanul Khalifa, Assulaimaniyah and Shohibul Iman), four institutions of the Madrasah Diniyah (Dakwatul Khair, Darus Sholihin, Nurul Mufidah and Assulaimaniyah), a boarding school (Khairul), as well as a Majelis Taklim, Dakwatul Khair.

In this case, it seems that the Dakwatul Khair Foundation is the largest institution in charge of educational units, namely, Islamic schools, boarding schools, assembly constituencies, Madrasah Tsanawiyah, and Madrasah Aliyah. The physical building of the Dakwatul Khair Foundation is located on a 5000 square meter waffle land and is located in Kumbak Luah, Setiling Village, North Batukliang District. Kumbak Luah is positioned at the far north end. Within 2 kilo meters of the foundation, there is no village, other than the jungle at the foot of Mount Rinjani. Some of the permanent buildings at the center of the foundation complex are a large mosque, 16 student dormitories, 8 study classrooms, teacher's room, and a multipurpose building (Observation, February 27, 2016).

The Dakwatul Khair Foundation is led by TGH Abdul Wasi (60 years), a teacher who had studied long enough in the holy land of Mecca. In August 1995, TGH Abdul Wasi began his activities in opening non-formal education, in the form of pesantren, majelis taklim, and 
diniyah. Then in 2006, he began to open formal education, namely Madrasah Tsanawiyah and Madrasah Aliyah.

Initially, the foundation used the term diniyah salafiyah. However, the term seems to invite questions from some people, remembering the term salafiyah is often identified with Wahabiyah. Moreover, the leader of the institution is the output of Saudi Arabia. As a result, the number of students studying has decreased, because for parents who are Sunni students, Wahhabism clearly has a difference with the understanding they believe in, and this is very sensitive. Finally, the foundation no longer used the term, it even began to open formal education in 2006 and the students returned (TGH Abdul Wasi, Head of Dakwatul Khair, interview on February 26, 2016).

The education base at the Dakwatul Khair Foundation is a pesantren. All students in various educational units in it are santri. In the sense that they learn to read the yellow book (kitab kuning). Diniyah's education is integrated into the formal education learning process. This policy is carried out so that all students have the opportunity to study the yellow book. This method is done with the reason that all students have the opportunity to study the yellow book. As a Middle-Eastern graduate, TGH Abdul Wasi wants all students to have the ability to read and understand the yellow book (kitab kuning).

Before formal education institutions opened in 2006, the existing structure of diniyah education used the Salafiyah Basic Education Program. The diniyah program lasted quite a long time and has produced several batches of graduates. But over time, especially at the instigation and needs of the community, the program was stopped and began to open up Tsanawiyah and Aliyah education. All Madrasah Diniyah students switch status to Madrasah Tsanawiyah and Madrasah Aliyah students, but the book reading activity remains or remains unchanged.

So since starting in the morning after the midday prayer in the congregation, all students have been preparing to go to their respective classes to learn the yellow book according to its schedule. The level of depth of the book that is read and studied is adjusted to the level of formal education. This activity ends at 09.00 for the dluha prayer. Furthermore, all students study formal education until the time of dzuhur prayer comes in the congregation, and continues until 14.00. After that, the break starts.

After the Asr prayer in the congregation, the students returned to class for one hour of deep English. Furthermore, after the Maghrib prayer in the congregation, all students attend the Koran recitation and starting from 21:00 to 22:00 back to deepening English. Tutors in English language study activities were pesantren alumni who were intentionally sent to study English in Pare Kediri, East Java. After completing their English education in Pare, they returned to the pesantren and devoted their knowledge (TGH Abdul Wasi, Head of Dakwatul Khair Foundation, interview on February 26, 2016).

For the study of the al-Qur'an, the students are divided into several groups of tahfizh according to their respective abilities. Specifically, there were about 20 students who memorized the al-Qur'an, both students of Madrasah Tsanawiyah and Madrasah Aliyah, especially female students. Until now, there have been 2 female students who have memorized 30 juz. The huffadz from this foundation are often included in the Musabaqah Hifdzul Qur'an at the Lombok Regency level.

The total number of diniyah students is 234 people, consisting of 99 Ulya students, 91 Wustha level students, and 55 Takhassus level students. 175 students live in the dormitory. The books studied by students at the Ulya level are Bulughul Maram, Anwarul Masalik, Fathul Qarib, Matan Zubad, Sarah Dahlan, Tajwid, Fathul Muin, Tafsir Jalalain, Hamsatun Mutun, Sirah, and Riadlus Shalihin. While the books for Wustha are Tajwid, Imla, Durusul 
Fiqh, Mahfuzhat, Sirah, Matan Jurumiah, Matan Takrib, Ahlaq lil Banin, Taklimul Muta'allim, Muhadasah, and the Qur'an. While the students of the Takhassus level studied Alfiah ibn Malik, Tafsir Jalalain and Faraid (TGH Abdul Wasi Leader of Dakwatul Khair Foundation, interview on February 28, 2016). While the number of educators and education personnel at the Dakwatul Khair Foundation is 43 people. Consists of 40 foundation permanent teachers, 1 temporary teacher, and 2 administrative staff. 7 teachers from all existing teachers have received certification funding allowances.

Unlike in Kabul Village, in Setiling Village the only other educational institution that manages formal education, besides the Dakwatul Khair Foundation is Nurul Irsyad NW. The educational institution manages the Madrasah Ibtidaiyah.

\section{Discussion}

Conducting a study of education in disadvantaged areas obtained a completely different finding of the reality of education services. If in other places people have talked about the issue of quality and expectations in the future that are measurable and planned about the performance of an educational institution, then those are expensive items that can only be present in the dreams of religious education managers in disadvantaged areas. This does not mean that they do not understand the quality of education, and neither do they strive to improve, but how to make the educational institutions they manage can survive is already an extraordinary struggle.

If a comparative study is conducted from the institutional side between the two underdeveloped villages, namely Kabul Village and Setiling Village, the number of religious education units in the two villages is sufficient, both Qur'anic educational institutions, diniyah, Islamic boarding schools, and majelis taklim. The two villages on average have more than one institution in each education unit.

Setiling Village is under the foot of Mount Rinjani with its position relatively further from the city center than Kabul Village, but the development of religious education is also quite good. The difference is precisely in the quantity of general education under the guidance of the Ministry of Religious Affairs, the madrasah institution.

There are far fewer madrasah institutions in Setiling Village than in Kabul Village. Another educational institution that manages formal education in Setiling Village, in addition to the Dakwatul Khair Foundation, is Nurul Irsyad NW, but this institution only manages the Madrasah Ibtidaiyah. While the development of religious education in Kabul Village is complemented by the presence of several public education which is far more adequate, such as Ibtidaiyah Ulumuddin, Ibtidaiyah Baitussalam, Ibtidaiyah Sirajul Ulum, and Ibtidaiyah Mambaul Ulum. For the level of Tsanawiyah, namely Tsanawiyah Ihya Ulumuddin and Tsanawiyah Baitussalam. As for the Aliyah level, namely, Aliyah Mambaul Ulum.

As an educational institution in a disadvantaged region, the Ihya Ulumuddin Foundation in Kabul Village and the Dakwatul Khair Foundation in Setiling Village, the two foundations which are the main focus of this study have made extraordinary efforts in carrying out intellectual intelligence by serving the educational needs of the school-age population. in both villages. The strength that exists in these two institutions is as is usually found in every nonformal educational institution, where the community has the enthusiasm and a very large contribution in it, not limited to initiating the establishment of the institution, even further than that is trying as much as possible manage and develop it all at once. 


\section{Conclusions}

It is realized that education is the responsibility of all parties, although in particular, the government has the mandate to carry it out. But of course, the government can't carry out the noble task of building education alone. Therefore, the participation of various parties, such as the community, the private sector, and social institutions, is very much needed for their participation in advancing education in Indonesia. However, once again it needs to be emphasized that the role of the community in developing education needs to be adequately supported by the government, especially in terms of funding. Educational funding is very crucial for private institutions that are managed directly by the community.

For example, when researchers ask about the source of funds issued by Ihya Ulumuddin Foundation in financing his operational activities, bearing in mind that about a hundred students living in the dorm were freed from all costs, free of charge, then he only answered emphatically; God! TGH Abdullah Lahaji's short answer is not of a single meaning. On the one hand, the answer implies an irony of real educational practice. Because the condition of the pesantren is so pathetic. The pesantren mosque is only a pile of red bricks that have been seen hollow in several parts. But precisely in that place hundreds of worshipers joined the majelis taklim activities every Saturday night. If boarding schools in urban areas are already using terraced beds, maybe even better than that, then the male santri hostel in Ihya Ulumuddin Foundation is only a semi-permanent building with slanted bamboo booths. While the santri's base for sleeping was only a woven pandanus woven mat that had been torn in several parts. Then, in such conditions, this pesantren must bear the operational costs of all students living in the pesantren.

While in Setiling Village, TGH Abdul Wasi developed several education units especially pesantren under the Dakwatul Khair Foundation. Unlike the Ihya Ulumuddin Foundation in Kabul Village, the physical building of the pesantren managed by TGH Abdul Wasi is much better organized, although it still cannot abandon its simplicity. The hope that the santri from the pesantren under the foot of Mount Rinjani wants to achieve is extraordinary. TGH Abdul Wasi combines integrated learning patterns. Although all students are directed to study formal education, the master teacher who is quite elderly still designs his students to learn the yellow book. For him, students must understand well the basics of Islamic religion from their primary sources. Therefore, the students are equipped with the ability to read and understand the yellow book well. Also, the students were given the provision of language skills. TGH Abdul Wasi chose English. One thing that needs to be appreciated very well is when he sent several senior students to study English at a well-known educational institution in Kediri, East Java. After graduating, they are given the responsibility to teach the knowledge they have gained at the Islamic Boarding School Dakwatul Khair.

The Ihya Ulumuddin Foundation and the Dakwatul Khair Foundation have affirmed their invaluable contributions to the progress of the nation's education, especially religious education. Its presence in disadvantaged areas does not make it a reason to remain silent waiting for the government's helping hand. It is on this site that the important points of community participation in the field of education. Even the added value must be pinned to them.

In this context, it is the government who should carry out affirmative action in serving the educational needs of the school-age population in disadvantaged areas. Without concrete policies from the government, especially the Ministry of Religious Affairs, religious education services in disadvantaged areas should be a priority to catch up with other more developed regions. This is where synergy is needed between the government and practitioners and 
movers of religious education in the region to open access to religious education services. In turn, this synergy can improve the quality of religious education services in disadvantaged areas so that they can compete with other educational institutions.

Acknowlegements. The author would like to thank profusely for the help and support of various parties in the research and report writing process. The Head of the Research and Development Center for Religious and Religious Education, Ministry of Religious Affairs has provided valuable opportunities and experience to study religious education in disadvantaged areas. While this research report cannot be prepared properly without a correction note from the reviewer team. Technical assistance was also provided by the administration team so that the research ran smoothly.

\section{References}

[1] http://garuda.ristekdikti. go.id/documents/detail/ 717052. Accessed January 2, 2019

[2] http://garuda.ristekdikti.go.id/ documents/detail/701919. Accessed January 1, 2019

[3] Muhadjir, Noeng: Qualitative Research Methods. Rake Sarasih, Yogyakarta (2002)

[4] Sugiyono: Understanding Qualitative Research. Alfabeta, Bandung (2008)

[5] Moleong, Lexy J: Qualitative Research Methods. PT Rosdakarya, Bandung (2004)

[6] https://id.m.wikipedia.org/wiki/Suku_Sasak. Accessed September 5 (2016)

[7] https://id.m.wikipedia.org/wiki/Boda. Accessed September 5 (2016)

[8] Central Lombok Statistics Agency: Central Lombok in Numbers 2014. BPS, Lombok (2014)

[9] Ministry of Education PKLN Bureau: Educational Profile of Central Lombok Regency. Ministry of National Education, Central Lombok (2016)

[10] http://www.academia.edu/ 1403474/pengembangan_koperasi_inan_dengan_masararakat_dan_swasta

[11] http://www.katawarta.com/ ekonomi-bisnis/wika-akan-buat-sodetan-overcomeinundation-terminal-3. Accessed August 15 (2016) 